\title{
TTR
}

Traduction, terminologie, re?daction

\section{European Translation Studies, Une science qui dérange, and Why Equivalence Needn’t Be a Dirty Word}

\section{Anthony Pym}

Volume 8, numéro 1, 1er semestre 1995

Orientations européennes en traductologie

URI : https://id.erudit.org/iderudit/037200ar

DOI : https://doi.org/10.7202/037200ar

Aller au sommaire du numéro

\section{Éditeur(s)}

Association canadienne de traductologie

ISSN

0835-8443 (imprimé)

1708-2188 (numérique)

Découvrir la revue

Citer cet article

Pym, A. (1995). European Translation Studies, Une science qui dérange, and Why Equivalence Needn’t Be a Dirty Word. TTR, 8(1), 153-176.

https://doi.org/10.7202/037200ar

\section{Résumé de l'article}

La Traductologie en Europe, Une science qui dérange, et Pourquoi "Équivalence » n'est pas forcément un gros mot - Les débats sur l'équivalence marquent le développement de la traductologie européenne depuis les années 1970 et constituent un cadre important de légitimation institutionnelle de la discipline. Un bref panorama de ces débats est effectué en appliquant à la traductologie les termes que Pierre Bourdieu utilise pour la défense de la sociologie, " une science qui dérange ». Ces débats se caractérisent, d'une part, par la légitimation précaire de l'équivalence linguistique dans les années 1970 et, d'autre part, par une série de critiques de l'équivalence - formulées au cours des années 1980 - dérivant de la priorité accordée aux facteurs cibles. Cependant, il est possible que la légitimation institutionnelle associée aux critiques de l'équivalence ait eu un effet désintégrateur sur la conceptualisation en traductologie et qu'elle ait été intellectuellement médiocre. Pour devenir une science proprement dérangeante, la traductologie pourrait revenir à l'équivalence en la considérant cette fois comme une illusion opératoire nécessaire à la définition et à la fonction sociale de toute traduction.

Tous droits réservés ( $\mathrm{C}$ TTR: traduction, terminologie, rédaction — Les auteurs, Ce document est protégé par la loi sur le droit d’auteur. L’utilisation des 1995 d'utilisation que vous pouvez consulter en ligne. 


\section{European Translation Studies, Une science qui dérange, and Why Equivalence Needn't Be a Dirty Word}

\section{Anthony Pym}

I take the term "translation studies" as an accepted and acceptable name for the general ruck of writings, debates, and research on aspects of translation. "European" here means whatever is talked about in a disintegrated Europe, which might as well extend to Israel, Sudan, the Philippines, or Texas. The expression une science qui dérange - roughly "a science that upsets" - is one of the ways Pierre Bourdieu describes his sociology in an interview published in 1980. To trace this latter reference is obviously to pose chestnuts like whether translation studies can legitimately be described as a "science." Less naively, however, the collocation proposes a specific conceptual frame, in fact a straight comparison. It asks if translation studies is or could be a science like Bourdieu's sociology. Is it in a position to upset anyone? If so, whom? If not, why not?

Debates over equivalence enter the scene as a major testing ground for these questions. They basically concern beliefs that some aspect of a source-text unit can equal some aspect of a target-text unit, although the points of contention are the nature, location, importance, and veracity of such beliefs. As such, the debates configure only one of several issues involving the status of 
translation studies. We could also look at relations with literary studies, or a certain latent capacity to upset closed visions of cultures. The issue of equivalence is by no means the only area in which translation studies has been caught between legitimation and provocation, between a desire to look like other disciplines and a potential to upset other disciplines. The debates over equivalence have nevertheless accrued singular historical depth and particularly polarized positions. Some think the idea of equivalence legitimates translation studies; others seem upset by this. I propose to recount a brief history of the dialectics involved, not without taking up a particular position myself. First, however, let me borrow a conceptual frame able to make the story interesting.

\section{Whom Might Bourdieu Upset?}

Much of what Bourdieu says about sociology should sound strangely familiar to scholars of translation:

Sociology has the sad privilege of being constantly confronted with the question of its status as a science. People are a thousandtimes less demanding with respect to history or ethnography, not to mention geography, philology, or archeology. Constantly questioned, sociologists constantly ask questions of both themselves and others. All this makes sociology look like an imperialistic science. How can a science that is scarcely beginning to stand on its feet be so presumptuous as to put other sciences under its microscope? Of course I believe sociology is a science. In fact, the questions it asks of other sciences are those that are particularly problematic for sociology itself. Sociology is a critical science because it is itself in a critical position. (1980, pp. 19-20, my translation, italics in the text.)

The question of scientific status - often expressed as scholarliness - has been similarly problematic for translation studies, and perhaps for reasons similarly associated with its position as a relative newcomer. Although we do not actually take other sciences as entire objects of study, the potential is built into the fact we draw on and question the approaches of the more established disciplines. Yet 
Bourdieu gives further good reasons why a science might upset people:

Because it reveals things that are hidden and sometimes suppressed, like the fact that success at school correlates not with 'intelligence' but with social background and more exactly with the cultural capital inherited from one's family. These are truths that technocrats and epistemocrats - that is, a good number of those who read and finance sociology - do not like to hear. (p. 20, italics in the text)

Is translation studies involved in the revelation of such truths, suppressed as in psychoanalysis (Bourdieu's term is refoulées) because socially disturbing? Are we in a position to upset those who read and finance our activities? Or do we lack the empirical paraphernalia, the questionnaires, the statistics and schemata that enable sociology to claim quantitative truths that are apparently neutral and objective? But for Bourdieu, who opposes his sociology to that of "social engineers" who would control individuals, the value of such scientific procedures is itself quite relative. Sociological findings are by no means discovered from a position of simple objectivity or neutrality:

The possibilities of helping to produce truth depend on two main factors: the interest one has in having the truth known (or inversely, in hiding it from others and from oneself) and the capacity one has to produce it. As Bachelard put it, there can only be a science of that which is hidden. Sociologists are best armed to dis-cover what is hidden when they have the best scientific weapons, when they best use the concepts, methods, and techniques developed by their predecessors [...]. And they are most "critical" when their conscious or unconscious intention is most subversive, when they are most interested in revealing that which is censored or suppressed in the social world. (pp. 22-23, italics in the text.)

Sociologists should use all the scientific weapons available to them, since they are involved in a conflictual situation from the outset. Yet the use of such arms does not exclude subjective investment on the 
part of the sociologist, who has an interest not only in revealing hidden things but also in appearing to be objectively disinterested about this process. Further, although subjective investment by no means invalidates the knowledge produced, recognition of this subjectivity requires that sociology undertake the sociology of sociologists, periodically turning its questions in on itself, objectifying rather than hiding the truth of its frail human dimension. Sociologists become one of the objects of their own scientific research.

This is not the place to explain all of Bourdieu. I cite these now classical passages merely to indicate a few of the points where comparison might help us relativize our own problems with equivalence, particularly the problems that concern ideals of objectivity and neutrality. The citations should nevertheless illustrate a few of Bourdieu's more general formulas like the need to "subjectify the objective" (apparently disinterested scientific truths are in the interest of a certain subjectivity) and, inversely, the need to "objectify the subjective" (the very material of such truths is the subjectivity of people involved in social practices, of which sociology itself is one). How might these statements apply to translation studies?

\section{In and Out of Equivalence}

In 1979 Werner Koller identified a "legitimation crisis" in European translation studies:

This science [Wissenschaft] has perhaps been more or less established as an independent discipline in some universities. But the relations and understandings between it and other fields of scientific inquiry is in no way unequivocal, settled, or unproblematic. We have not (yet) overcome the legitimation crisis concerning the relation between translation science and translation practice, nor that between translation science and other scientific disciplines such as contrastive linguistics and stylistics, comparative literature, and computational linguistics. (1979, p. 10; my translation.) 
This seems to imply that translation studies was already doing the right things. It just had to be formally legitimated, especially with respect to its neighboring disciplines. But did anyone imagine this could be done without conflict? Given the limitations on university budgets, on student enrollments, and on publication possibilities, the emergence of a new discipline surely implied some degree of submergence for others. Particularly where translation was traditionally taught in departments of language and literature, the association of an independent translation studies with the independent training of translators was bound to create tension and confrontation'. Opposition on this institutional level could not help but question the scientific legitimacy of translation studies. Subjective interests motivated arguments for and against scientific status, and did so in a way that was rather more demanding than might have been the case for many of the more established disciplines.

Koller's response to this problem, elaborated in his Einfuihrung of 1979, was to bring together and systematize much of the work that had already been done. In practice, he assumed the essential solution had already been found. It just had to be cleaned up, put on show, and developed. A major part of this solution was the notion of translational equivalence. Yet this term was not just pulled out of a hat. It had its reasons, and it even had a mildly revolutionary import.

Koller presented translational equivalence as an argument against theories of general untranslatability (this opposition is further stressed in the revised fourth edition of 1992), cutting across what were at that time all-embracing debates about linguistic relativity or language universals ${ }^{2}$. Since translational equivalence was seen as

1. See Caminade in this volume.

2. Koller's translational equivalence, focused on the level of parole, was certainly designed to overcome the deadlock between relativist and universalist linguistics. But it had little effect on 
existing on the level of translation as language use (parole), it was not reducible to formal correspondences or differences between language systems. This was something that could potentially upset theories that were so lost in language systems that they failed to see the actual pragmatics of translation. Georges Mounin had actually deployed much the same strategy more than a decade earlier, following the rediscovery of Saussure and the rise of relativist structuralism: "If the current theses on lexical, morphological, and syntactic structures are accepted, one must conclude that translation is impossible. And yet translators exist, they produce, and their products are found to be useful" (1963, p. 5). Since translators and translations existed, translation must be possible and equivalence must therefore exist as well. Such was the general argument in favor of translational equivalence as a concept able to challenge a certain closed linguistics. The study of language systems had suppressed translation; theories of equivalence could dis-cover translation. Of course, there was a troublesome gap between the social existence of translations and the linguistic analysis of substantial equivalence. But this gap seems not to have bothered the translation theorists of the 1970 s. Their argument was strategic, contestational, and reasonably successful as a bid for legitimation.

Bear in mind that Koller was writing at a time when a few tons of linguistics, from Hjelmslev to Catford and Searle, could be cited in support of translatability and thus as a basis for equivalence. Koller's theorizing was and remains an affair of language; there was no need to oppose the whole of linguistics. This was very useful in 1979. It could effectively pass on some of the authority of what was still the most prestigious of the human sciences. Theorists of equivalence could moreover be presented as technical engineers interested in the better control of translation as a social practice. Their aim was the regulation and improvement of standards (as

classical conflicts between word and sense. Indeed, dichotomies like Nida's "formal equivalence" and "dynamic equivalence" dressed the classical word-versus-sense debate in the clothes of equivalence. 
explicitly stated in texts like Reiss 1971). Equivalence thus became a piece of scientific capital, stretching out into a general paradigm with a few ounces of institutional power. It provided the foundation for research programmes supposedly useful for both machinetranslation research and translator training. These fields in turn responded to the rising social and political demand for controllable transcultural communication, particularly in what was then the European Community. Translation studies was made to look like a science worthy of financial support. It was also made to look like applied linguistics. As such, the equivalence paradigm enjoyed a degree of success in advancing the cause of moderately independent research programmes and translator-training institutes. The concept was institutionalized. And no one had much time for the paradigm that had supposedly been upset, the belief in untranslatability.

Yet the 1980s had other concepts up its sleeve. The decade would see linguistic concepts of translational equivalence challenged in at least two ways.

For the historico-descriptivism of Toury (1980), equivalence was something automatically produced by all ostensible translations no matter what their linguistic or aesthetic quality. Thus defined, the concept was rendered effectively useless for linguists, technocrats, and anyone else interested in Koller-like legitimation. If equivalence was already everywhere, or almost, it could not be used prescriptively. Would-be social engineers could make no use of it to improve social communication. Worse, it could not easily support concrete institutionalization in the fields of machine translation or translator training. For Toury, the confidence of linguistic experts should logically give way to detailed descriptive work on actual translations in their historical contexts. If equivalence had upset no more than the occasional belief in untranslatability, Toury's extension of it at least had the potential to upset prescriptive linguists and pedagogs.

For the target-side functionalism of Vermeer, on the other hand, equivalence was only one of many goals that a translator could set out to attain, since translations could serve a range of 
communicative purposes $(1989$, p. $120 \&$ passim). The determinant on translation was not the source text, as had been assumed by linguistic approaches to equivalence, but the intended function or Skopos of the translation as a text in its own right and in its own situation. This so-called Skopostheorie was also potentially upsetting, at least for linguists and teachers of translation who had never looked beyond source-text criteria.

As revolutionary as these two approaches could have been, neither of them denied that a translator could set out to produce one kind of equivalence or another. Nor did they deny scientific objectivity as an essential goal for translation studies. They simply refused to base their scientific status on equivalence. They chose other weapons. Toury and friends have invoked systems, hypotheses, empirical testing, and the search for probabilistic laws. Vermeer and company have developed a rich assortment of technical-sounding names for various aspects of translation, combining discursive precision with metalinguistic elitism. One of the curious outcomes is that whereas Toury helped develop a mode of corpus-based research where "a translation is any target-language utterance which is presented or regarded as such" (1985, p. 20), Vermeer's influence fits in with the fact that prospective students at Heidelberg are told that the institute's German term Translation (not Übersetzen) does not correspond to "the translating and interpreting that unthinkingly duplicates linguistic forms and structures" ("das unreflektiert Sprachformen und -strukturen nachvollziehende 'Übersetzen' und 'Dolmetschen'.")(1992, p. 2). For historico-descriptivists, translation is anything people commonly think it is (social practice can't be wrong). For the Heidelberg text, translation is precisely not what people commonly think it is, especially if they imagine it is a matter of producing equivalents for source texts (social practice can be correctively engineered). In the first case, science is empirical investigation; it goes out into the world and can advance on the basis of the material it analyzes. In the second, science is a matter of knowing what others have to find out; students come to you and advance on the basis of your theoretical expertise (and if social agents don't always know what a translation really is, they too can become your students). Clearly, neither of these approaches needed 
a strong concept of equivalence, which soon seemed unable to objectify anything of interest about translation. Having become either too large (for Toury et al.) or too small (for Vermeer et al.), the concept gradually lost its status as scientific capital. It became a dirty word.

What really happened here? The dates could be misleading. Koller published in 1979, but his text survived through four editions to 1992 and is still worth reading. Toury was published in book form in Israel in 1980, but his work has taken years to filter through to some kind of general recognition. The writings of Vermeer and friends, published mostly in German and often in small university editions, has been so slow to catch on that the group still feels revolutionary more than ten years after the Grundlegung einer allgemeinen Translationstheorie of 1984. The space of European translation studies is spread so thinly and remains so fragmented that these various paradigms have mostly managed to co-exist in tacit ignorance of each other. There is no evidence of any catastrophic debate being resolved one way or the other. Critique and change have been more the stuff of a general drift directed by minor pushes and pulls in many isolated parts of the world. The details are no doubt best told by the scholars involved. Yet there can be little doubt that the general trend was away from equivalence and toward target-side criteria. Of course, this was more or less in keeping with the movement of linguistics toward discourse analysis, the development of reception aesthetics, the sociological interest in action theory, and the general critique of structuralist abstraction. European translation studies was no hotbed of intellectual originality. Nor is it a dialectician's paradise today.

The approaches on the rise in the 1980s nevertheless dis-covered a previously suppressed (or insufficiently recognized) truth, namely the social and historical relativity of translational equivalence. Many of the linguistic categories that had previously been considered objective could now have been seen as largely subjective constructs. Beyond the restricted field of specialized terminology, theorists could no longer be sure that a given source-text unit was necessarily equivalent to a specific target-text 
unit. Such a relation could only be norm-bound or probabilistic (for Toury) or subordinate to wider target-side considerations (for Vermeer). There would always be at least residual doubt about general claims to equivalence.

This doubt should probably have undone the entire equivalence paradigm. It should have revealed the subjective interest that the theorists of equivalence - and their institutional supporters - had had when they tried to found a science of translation. We might say, with Bourdieu, that the objective could have been subjectified. The 1980 s approaches could have done this. They could have become radically upsetting. But they didn't. Why not?

\section{The Critique of Equivalence}

Almost ten years after Koller's Einführung, Mary Snell-Hornby's "integrated approach" of 1988 sought to bring together and systematize the work that had been done to that date. As in Koller, the underlying assumption was that a certain compatibility was there; it just needed to be "integrated." The package was once again made to look faintly scientific, this time privileging American panaceas like prototypes and scenes-and-frames, along with a potpourri of common sense, and a disarming propensity to self-contradiction (notably with respect to the status of linguistic approaches). One of the most remarkable aspects of this "integrative" exercise was the list of effectively excluded approaches. Snell-Hornby's peremptory style dismissed two thousand years of translation theory as an inconclusive "heated discussion" opposing word to sense $(1988$, p. 9) (one finds the same inconclusiveness in theories of God, or love, and yet we keep talking). She dispatched historico-descriptivism because it had avoided evaluation (p. 26) (but hadn't it discovered anything?). Not surprisingly, she also forcefully discarded equivalence as being "unsuitable as a basic concept in translation theory" (p. 22). None of these excluded approaches, said Snell-Hornby, "have provided any substantial help in furthering translation studies" (p. 26). The interesting thing about these exclusions is that, unlike Toury or Vermeer, Snell-Hornby tried to indicate precisely where the 
equivalence paradigm had gone wrong. This is where translation studies could have become truly upsetting.

Some of the things Snell-Hornby says about equivalence are perceptive and stimulating ( 1 use a precarious present tense because the text is due to be published in a revised edition). For example, she finds that in the course of the 1970s the English term "equivalence" became "increasingly approximative and vague to the point of complete insignificance," and its German counterpart (but what criterion did she have for putting the two terms together?) was "increasingly static and one-dimensional" (p. 21). This difference curiously maps onto the strategies of Toury and Vermeer as outlined above, suggesting that there was in fact no radical rupture between those who talked about equivalence and those who preferred not to (Toury accepted the English-language trend; Vermeer fell in with the German-language usage of the term). Summing up a very meandering argument, Snell-Hornby concludes that "the term equivalence, apart from being imprecise and ill-defined (even after a heated debate of over twenty years) presents an illusion of symmetry between languages which hardly exists beyond the level of vague approximations and which distorts the basic problems of translation" (p. 22). Some kind of equivalence could be integrated into its appropriate corner (technical terminology), but the equivalence paradigm should otherwise get out of the way. All potentially upsetting stuff.

Snell-Hornby did not care that notions of equivalence had been strategically useful against theories of untranslatability, nor that they had effectively achieved a degree of institutional legitimation for translation studies. Hers was a different historical moment, with different strategies and goals. But even given the new context, at least one sleight of hand should be pointed out. If the term "equivalence" were really so polysemous - Snell-Hornby elsewhere claims to have located fifty-eight different types in German uses of the term $(1986$, p. 15$)-$, how could she be so sure it "presents an illusion of symmetry between languages"? The term apparently means nothing except this illusion. And yet none of the numerous linguists cited in Koller ever presupposed any "symmetry between 
languages." Since Snell-Hornby gives no citation supporting her reduction of the term, this description of equivalence looks like hers. Of little import that the idealized symmetry between languages belonged more to the word/sense debate that Snell-Hornby strangely thinks the notion of equivalence had been born to overcome (p. 15). Indeed, had she looked a little further, Snell-Hornby might have found that concepts like Nida's "dynamic equivalence" presuppose substantial linguistic asymmetry. More important, Koller's actual proposal was based on studying equivalence on the level of parole, leaving to contrastive linguistics the entire question of symmetries or dissymmetries between language systems (1979, pp. 183-184). Where did Snell-Hornby get the idea that equivalence means "symmetry between languages"? She seems to have presented a limited range of variant usages, picked or projected the illusion that suits her, then assumed that everyone else suffered from the same hallucination.

This was indeed moderately upsetting. Albrecht Neubert has observed the strategy clearly enough: "The narrow and hence mistaken interpretation of translational equivalence in terms of linguistic correspondence is in our opinion one of the main reasons that the very concept of equivalence has fallen into disrepute among many translation scholars." (1994, p. 414). That's more or less what has happened. But why did it happen?

One can only suppose there was more than logic at stake in Snell-Hornby's critique of equivalence. An element of power, perhaps? Snell-Hornby's Integrative Approach has indeed had influence, and may yet find more. It was the right title at the right time, lying in wait for the massive growth of translator-training institutions that took off at the end of the decade.

Yet this is not the story of just one person. There is more at stake in the movement away from equivalence. Strangely, while European translation studies has generally been expanding, a center of strong equivalence-based research at Leipzig, closely associated with Professor Neubert, has been all but dismantled by west-German academic experts. Further, the one west-European translation 
institute that has been threatened with reduction - Saarbrücken - is precisely the one that, through Wilss, is most clearly aligned with linguistics and the equivalence paradigm ${ }^{3}$. This is not to mention the numerous east-Europeans who still - heaven forbid! - talk about linguistics and equivalence, awaiting enlightenment from the more advanced western theorists. The institutional critique of equivalence surreptitiously dovetails into facile presumptions of progress, and sometimes into assumptions of west-European superiority. Perhaps we should take a good look at the bandwagon before we hop on.

\section{Understanding Equivalence}

Although the 1980 s critiques of equivalence-based prescriptivism opened up new terrain, they mostly failed to understand the logic of the previous paradigm. Little attempt was made to objectify the subjective importance of equivalence as a concept. It is one thing to argue that substantial equivalence is an illusion, but quite another to understand why anyone should be prepared to believe in it. A pertinent lesson might be gleaned from Bourdieu:

There is an objective truth of the subjective, even when it contradicts the objective truth that one constructs against it. Illusions are not in themselves illusory. One would betray objectivity if one acted as if social subjects had no representation, no experience of the realities that are constructed by science [...]. Sociology should not forget that in order for social practices to work, social actors must believe they are the ones who make their actions work. Some systems work entirely on belief, and no system - not even economics - can do without the belief that it can work. $(1980$, p. 32)

Illusions are not illusory. Yet when Snell-Hornby talks about "the illusion of equivalence" $(1988$, p. 13), she does so precisely to

3. It is to Professor Snell-Hornby's credit that, as President of the European Society for Translation Studies, she has spoken out against the reduction of Saarbrücken. 
suggest that it is illusory and should be dispensed with. The main alternative to this strategy is to understand and explain the illusion.

This second strategy has been adopted by several isolated authors. Ernst-August Gutt, whose application of relevance theory to translation deserves more attention than it has so far received, defines a "direct translation" as an utterance that "creates a presumption of complete interpretative resemblance" (1991, p. 186). True, Gutt does not name equivalence as such - it is a taboo word -, but he certainly describes what equivalence would seem to be doing when a translation is read as a translation. More important, this "presumption of resemblance" does not describe anything that would enable a linguist's tweezers to pick up two pieces of language and declare them of equal weight. Comparable considerations enter Albrecht Neubert's recent comments on equivalence. A translation, says Neubert, "has to stand in some kind of equivalence relation to the original," which means that "equivalence in translation is not an isolated, quasi-objective quality, it is a functional concept that can be attributed to a particular translational situation" (1994, pp. 413-414, italics in the text). From the semiotic perspective, Ubaldo Stecconi expresses a similar mode of thought: "Equivalence is crucial to translation because it is the unique intertextual relation that only translations, among all conceivable text types, are expected to show" (forthcoming). Such "expectation" is certainly an affair of social convention rather than empirical certainty, but it has consequences for the actual work of the translator. In Stecconi's terms, "B had never been equivalent to $\mathrm{A}$ before it appeared in a translation: using inferences of the abductive kind, the translator makes the two elements equivalent" (ibid.). A fourth researcher could be cited here: Pym (1992) spends a whole chapter arguing that "equivalence defines translation," and in a further text (1993) talks about non-relativist and non-linguistic "equivalence beliefs" as part of the way translations are received as translations.

These authors form no kind of group; they are more like lone voices in disparate wildernesses. But they are not naïve theorists who blissfully ignore the critiques of equivalence. Despite apparent regression to the 1970 s paradigm, these recent positions are 
in fact exploiting the gap between translation as a social practice (equivalence as a necessary and functional illusion) and translation as actualization of prior correspondences (equivalence as something that linguists might hope to analyze on the basis of language alone). This is precisely the gap that Mounin and Koller, among others, had previously swept under the carpet in the interests of legitimation. The minority return to equivalence is thus dis-covering a problem that previous usages of the term had played down ${ }^{4}$. It could even be drawing out the critical potential of something like Toury's initial acceptance of equivalence. Rather than force any translator to become an "equivalence-seeker"(Mossop, 1983, p. 246), rather than assume any "rational recovery of original meaning" (Benjamin 1989, p. 86), the above writers emphasize that the translator is an equivalence producer, a professional communicator working for people who pay to believe that, on whatever level is pertinent, $A$ is equivalent to $\mathrm{B}$. In so doing, the recent references to equivalence are objectifying the subjective, recognizing but not necessarily condoning a socially operative belief that enables translations - and translators - to work. This position is commonly misunderstood.

The linguistics-derived concept of equivalence was an expression of what translation ideally represented for certain people, notably translators' organizations in search of higher social status, readers in search of translated information, European politicians in search of reliable transcultural communication, and academics in search of authoritative science. It expressed certain ideals of translation as a contemporary social practice. Theories that now project little substantial equivalence - whether or not they use the term - should nevertheless be able to recognize and objectify the subjective interests that make translation work as a social practice. Translation studies cannot just put texts under linguistic microscopes. It must also objectify the beliefs - the current but

4. Koller, it should be noted, had already talked about translation as the production (Herstellen) of equivalence (1979, pp. 187-190), although the significance of the term seems not to have been realized. 
uncritical term is "norms" - that condition the way translations are received and thus the way translators tend to work. Such subjective beliefs obviously include the illusions that remain operative on the level of theory.

\section{Solutions without Equivalence}

Gutt, Neubert, Stecconi, and Pym (there could be more names) have something else in common. Their arguments recuperate the very important idea that translation and non-translation are conventionally distinguished, since the making of this distinction is one of the functions of equivalence itself. They thus have a certain interest in defining translation in a restrictive way; they are not afraid to distinguish translation from non-translation.

If we now look at the critiques of equivalence, one feature seems surprisingly common to the various groups concerned. In contradistinction to the four authors just cited, none of the theorists that oppose equivalence appears to have advanced a restrictive definition of translation. There are certainly many descriptions; they all say what a translation should look like and should do. Try, for example, Snell-Hornby's description beginning "Translation is a complex act of communication in which..." (1988, p. 81). Nowhere in the page or so of text that follows is there anything about what translation is not. There are no definitions of non-translation. Everything can be fitted in; everything is potentially translative; so translation studies might as well encompass cultural studies, literary studies, the entire humanities, and more, if it would make anyone happier or more powerful. The rejection of equivalence quickly leads to a peculiarly uncentered conceptual expansion, the nature of which is still far from clear.

Equivalence, on the other hand, no matter what definition it figured in during the bad old days, always implied the possibility of non-equivalence, of non-translation or a text that was in some way not fully translational. This in turn configured translation studies as a quite specific neck of the academic woods. The $1980 \mathrm{~s}$ thus saw a shift from restrictive to non-restrictive definitions, from 
translation studies as a focused and unified discipline to translation studies as an area potentially open to all comers.

The shift was not without friction. Not everyone agrees that a translation can be a bibliographic reference (as in Gouadec 1989) or any text explaining foreign information (as in Holz-Mänttäri 1984) or indeed any text at all (as in theories of radical intertextuality). The change has nevertheless been institutionally successful. It has inspired several good propositions for new disciplinary frames, including "transfer studies" (after Even-Zohar 1990), action theory (Holz-Mänttäri 1984; Vermeer 1986, 1989), and "rewriting" (Lefevere 1985, 1992). Strangely enough, most of the authors producing restrictive definitions of translation, the ones who place equivalence (or its surrogates) in the space of production and reception, also work within wider conceptual frames, be it relevance theory (Gutt), semiotics (Stecconi), or negotiation theory (Pym, 1992, and forthcoming). This is a general trend; the conceptual expansion now exists whether or not one refers to equivalence. In training institutes, the new perspectives have supported numerous degree and diploma programmes combining translation with cultural studies, literary studies, documentation, terminology, international relations, commerce, computer science, and so on ${ }^{5}$. Everyone seems to agree on the need for a wider frame. To produce equivalence is nowadays not the end of the story, neither for the theorist nor for the pedagog. There is thus little subjective interest in restrictive definitions of translation. They exist, they stubbornly refer to equivalence, but they are not about to upset anyone. Once again, why not?

\section{Legitimation Achieved?}

If we now go back to Koller's "legitimation crisis" of 1979, we find that a kind of legitimation for translation studies has in fact been found. Koller thought the answer was to define translation studies as a science and to regulate its relations with neighboring

5. See Caminade in this volume. 
disciplines. But on the ground, the historical solution has been to deregulate relations, allowing translation to be studied in any number of disciplinary locations, in terms of any number of non-restrictive definitions. Instead of a wholly independent translation studies, we now have a fairly unruly grouping of approaches and interests that cover far more than any equivalencebound definition of translation. Gideon Toury's description of translation studies as an "interdiscipline" is currently as accurate as it is widely accepted (a very large congress held in Vienna in 1992 was actually called "Translation Studies, An Interdiscipline"). There is also a level of civil organization that should prove greater than any formal theory. As Althusser was wont to say, the solution to theoretical problems already exists on the level of practice, if you know where to look. Non-restrictive deregulation has been the practical solution, although not necessarily the best one.

Whereas Snell-Hornby sought to enact a centered integration in the 1980s, an upsetting sociology could now show that successfully uncentered disintegration was going on at the same time. This second reality, the historical solution to a legitimation crisis, is still worth dis-covering.

\section{A Summary}

Since debates over equivalence are not always easy to follow, here is a brief summary of the way I have called the shots:

- Structuralist linguistics of language systems (Saussure et al.) overlooked the social existence of translation.

. The concept of translational equivalence (Koller et al.) affirmed the social existence of translation and sought to make it a part of applied linguistics.

. Historico-descriptive studies (Toury et al.) rejected the prescriptive import of such linguistics and affirmed that equivalence was a fact of all translations, no matter what their quality.

. Theories of target-side functionalism (Vermeer et al.) similarly rejected such prescriptivism, limiting equivalence to cases where the translation purpose was narrowly bound by source-text elements. 
. Thanks to these two movements, the notion of equivalence lost its status as a scientific concept (most radically in the work of Snell-Hornby).

- Translation studies has thus expanded well beyond the academic space once centered on equivalence.

- A few isolated voices, including the present author, have nevertheless recuperated the notion of equivalence as an affirmation of the social existence of translation, without associating the term with any prescriptive linguistics. They thus reveal the inability of expansive translation studies to offer a restrictive definition of translation.

\section{Envoi}

In 1992, Susan Bassnett and André Lefevere declared that "[t]he growth of translation studies as a separate discipline is a success story of the 1980s" (1992, p. xi). Success for whom? And at what price? It is worth recalling that Lefevere, in an article published just one year before, argued against an independent translation studies, which he regarded as "most unlikely to make the distinction between literary and non-literary, or technical translation" (1991, p. 131). Success, for Lefevere, was obviously a question of keeping translation studies attached to literary studies, just as others wanted to keep it attached to linguistics, and still others could see nothing but translator training. Squabbles about equivalence marked the borders between these various visions of academic paradise. Success for me, of course, would be a translation studies inspired by Bourdieu's sociology. We all have our private backgrounds and agendas.

It must nevertheless be admitted that translation studies has expanded in more than one direction. The reasons are perhaps not always obvious. Youth unemployment means students enrol in something that sounds marketable; European integration means some national politicians are willing to fund practical-sounding translation research; and some literature departments, at various stages of conceptual bankruptcy, have managed to hitch a ride into unknown territory. Few would claim that translation studies has really 
succeeded as an academic discipline with something of its own to say to other disciplines. In significant contradistinction to developments on the other side of the Atlantic, European translation scholars have been strangely reluctant or unable to engage in wider social or academic debates. Although translation inevitably concerns extremely problematic phenomena like traditional canons, cultural specificity, political identity, and nationalist combinations of all three, most theorists have stayed clear of such turbulent waters. There has been virtually no deconstruction, little feminism ${ }^{6}$, scant critique of European east-west relations, no more than lip-service to the translation costs that risk crippling the European Union, and minimal critique of a thing called "culture" that remains so vague it couldn't upset anyone's idea of a culture. Translation studies remained intellectually mediocre throughout the $1980 \mathrm{~s}$ and is struggling to find orientation in the 1990s. Many of its theoretical efforts have been directed toward gaining academic power rather than identifying and solving significant social problems. Now enjoying what some see as success, with or without equivalence, European translation studies upsets virtually no one. Such has been the price of its disintegrative expansion.

Anthony Pym: Universitat Rovira i Virgili, Departament de filologia anglo-germanica. Plaça Imperial Tarraco, 1 - 43005 Tarragona, España.

\section{References}

BASSNETT, Susan \& André LEFEVERE (1992). "General editors' preface," in André Lefevere, ed. Translation, History, Culture. A Sourcebook. London and New York, Routledge.

6. See von Flotow in this volume. 
BENJAMIN, Andrew (1989). Translation and the Nature of Philosophy. A New Theory of Words. London and New York, Routledge.

BOURDIEU, Pierre (1980). "Une science qui dérange," interview with Pierre Thuillier, la Recherche 112 (June). Reprinted in Questions de sociologie. Paris, Minuit, 1980, pp. 19-36.

EVEN-ZOHAR, Itamar (1990). "Translation and Transfer," Poetics Today XI(1) [special issue on Polysystem Studies], pp. 73-78. First version published as "Translation Theory Today: A Call for Transfer Theory," Poetics Today II(4) (1981), pp. 1-7.

GOUADEC, Daniel (1989). Le Traducteur, la traduction et l'entreprise. Paris, Afnor.

GUTT, Ernst-August (1991). Translation and Relevance. Cognition and Context. Oxford, Blackwell.

HEIDELBERG UNIVERSITY (1992). Studienfïhrer Dolmetschen / Übersetzen. Heildelberg, Institut für Übersetzen und Dolmetschen.

KOLLER, Werner (1979). Einführung in die Übersetzungswissenschaft. Heidelberg, Quelle \& Meyer. 4. Auflage 1992. (Page references are to the first edition.)

LEFEVERE, André (1985). "Why Waste our Time on Rewrites? The Trouble with Interpretation and the Role of Rewriting in an Alternative Paradigm," in Theo Hermans, ed. The Manipulation of Literature. Studies in Literary Translation. London \& Sydney, Croom Helm.

(1991). "Translation and Comparative Literature: The Search for the Center," TTR IV(1), pp. 129-144.

(1992). Translation, Rewriting and the Manipulation of Literary Fame. London and New York, Routledge. 
MOSSOP, Brian (1983). "The Translator as Rapporteur: A Concept for Training and Self-Improvement," Meta XXVIII(3), pp. 244-278.

MOUNIN, Georges (1963). Les Problèmes théoriques de la traduction. Paris, Gallimard. New ed. 1976, coll. Tel.

NEUBERT, Albrecht (1994). "Competence in Translation: a Complex Skill, How to Study and How to Teach it," in M. SnellHornby et al. eds. Translation Studies. An Interdiscipline. Amsterdam and Philadelphia, John Benjamins, pp. 411-420.

PYM, Anthony (1992). Translation and Text Transfer. Frankfurt/Main, Lang.

(1993). Epistemological Problems in Translation and its Teaching. Calaceite, Caminade.

$\overline{\mathrm{XL}(4), 1995 .}$

(forthcoming). "Translation as a Transaction Cost," Meta

REISS, Katharina (1971). Möglichkeiten und Grenzen der Übersetzungskritik. Munich, Max Heuber Verlag, Heuber Hochschulreihe 12.

REISS, Katharina \& Hans J. VERMEER (1984). Grundlegung einer allgemeinen Translationstheorie. Tübingen, Niemeyer.

SNELL-HORNBY, Mary (1986). "Übersetzen, Sprache, Kultur," in Mary Snell-Hornby, ed. Übersetzungswissenschaft. Eine Neuorientierung. Tübingen, Francke.

(1988). Translation Studies. AnIntegrated Approach.

Amsterdam and Philadelphia, John Benjamins.

STECCONI, Ubaldo (forthcoming). "Semiotics in Translation Teaching," paper presented to the conference Problems and Trends in the Teaching of Interpreting and Translation. Centro 
Internazionale di Studi sull'Interpretazione e la Traduzione, Misano Adriatico, September 28-30, 1994.

TOURY, Gideon (1980). "Equivalence and Non-Equivalence as a Function of Norms," In Search of a Theory of Translation. Tel Aviv, Porter Institute, pp. 63-70.

VERMEER, Hans J. (1986). Voraussetzungen für eine translationstheorie. einige kapitel kultur- und sprachtheorie. Heidelberg, Institut für Übersetzen und Dolmetschen. Institut für Übersetzen und Dolmetschen.

(1989). Skopos und Translationsauftrag. Heidelberg,

ABSTRACT: European Translation Studies, Une science qui
dérange, and Why Equivalence Needn't Be a Dirty Word Debates about equivalence have marked the development of European translation studies since the 1970 s, forming a significant frame for the institutional legitimation of the discipline. A brief survey of these debates, carried out in terms of Bourdieu's defence of sociology as an "upsetting" science, distinguishes between the precarious legitimation of linguistic-based equivalence in the $1970 \mathrm{~s}$ and several target-side critiques directed at the concept in the $1980 \mathrm{~s}$. However, the alternative institutional legitimation associated with the critiques of equivalence may well have been conceptually desintegrative and intellectually mediocre. It is concluded that translation studies could now become properly upsetting by returning to equivalence and considering it as an operative illusion necessary for the definition and social function of any translation.

RÉSUMÉ: La Traductologie en Europe, Une science qui dérange, et Pourquoi «Équivalence» n'est pas forcément un gros mot - Les débats sur l'équivalence marquent le développement de la traductologie européenne depuis les années 1970 et constituent un cadre important de légitimation institutionnelle de la discipline. Un bref panorama de ces débats est effectué en appliquant à la traductologie les termes que Pierre Bourdieu utilise pour la défense 
de la sociologie, «une science qui dérange». Ces débats se caractérisent, d'une part, par la légitimation précaire de l'équivalence linguistique dans les années 1970 et, d'autre part, par une série de critiques de l'équivalence - formulées au cours des années 1980 - dérivant de la priorité accordée aux facteurs cibles. Cependant, il est possible que la légitimation institutionnelle associée aux critiques de l'équivalence ait eu un effet désintégrateur sur la conceptualisation en traductologie et qu'elle ait été intellectuellement médiocre. Pour devenir une science proprement dérangeante, la traductologie pourrait revenir à l'équivalence en la considérant cette fois comme une illusion opératoire nécessaire à la définition et à la fonction sociale de toute traduction. 